ing on the rights of authors. It now remains for individuals and groups in the profession to use their professional knowledge and their understanding of the internal ramifications of the copyright law on library services to offer guidance and counsel to the interpreters of the law so that ambiguities can be eliminated and practice become uniform and so that library services will not be seriously hampered.

\section{BIBLIOGRAPHY}

American Library Association. Librarian's Guide to the New Copyright Law. Chicago: The Association, 1977. (Reprinted from the Washington Newsletter, Nov. 15, 1976.)

American Library Association and National Education Association. The New Copyright Law: Questions Teachers and Librarians Ask. Washington: National Education Assn., 1977.

Shemel, Sidney. This Business of Music. Rev. ed. New York: Billboard Publications, 1974.
Special Libraries Association. Library Photocopying and the U.S. Copyright Law of 1976: An Overview for Librarians and Their Counsel. New York: The Association, 1978.

U.S. Congress. House. Copyright Law Revision. (HR 94-1476) 94th Congress, 2d Session. Sept. 3, 1976. Washington, D.C.; Govt. Print. Off., 1976.

U.S. Congress. Senate. Copyright Law Revision. (SR 94-473) 94th Congress. 1st Session. Nov. 20, 1975. Washington, D.C.: Govt. Print. Off., 1975.

U.S. Copyright Office. Copyright and the Librarian. Circular R21. Washington, D.C.: Govt. Print. Off, 1977.

U.S. Copyright Office. General Guide to the Copyright Act of 1976. Washington, D.C.: Govt. Print. Off., 1977.

U.S. Copyright Office. Highlights of the New Copyright Law. Circular R99. Washington, D.C.: Govt. Print. Off, 1977.

\title{
Some Responses on Copyright
}

Editor's note: In the January issue C\&RL News invited responses to Charles Martell's "Copyright Law and Reserve Operation." As space permits, we will print those responses.

\section{COPYING FOR RESERVE READING- A DIFFERENT VIEWPOINT}

Many academic libraries appear to be extending the use of the CONTU Guidelines to provide a legal basis for reserve room copying. Some interpret the reserve room as being an extension of the classroom, thus multiple copies for classroom use could also be for reserve room use.

Late last year, and after careful study, Northern Illinois University Library chose not to follow such a course. The librarians, with the advice of the university's legal counsel, decided that reserve copying could not meet the three criteria established to justify multiple copies for classroom use; namely, brevity, spontaneity, and cumulative effect. In the library's experience, reserve copying frequently exceeds 2,500 words or 10 percent of a work. The fact that a professor requests, weeks in advance, that a copy be placed on reserve defeats any pretense of spontaneity. Some reserve reading lists include many more than the nine articles per class term recommended under the rubric, "cumulative effect." A lack of any other guidelines to Section 108 of the Copyright Law led the librarians to the conclu-

\section{A PERSONAL VIEW FROM PENN STATE}

I found Charles Martell's January article, "Copyright Law and Reserve Operations," interesting but naive. Let me accept your invitation to respond to that article and explain my impressions of it.

I agree with Martell that faculty members should be made aware of the new restrictions on photocopying and the distribution of reserve materials. I disagree that "the individual teacher should ... request copyright approval from [its] holder if multiple copying is required."

Librarians, not the teaching faculty, should take the initiative in these dealings with authors and publishers so that they can compile records that prove they have acted in good faith. This ability to prove good faith compliance is necessitated by the fact that libraries act as co-owners and distributors of the photocopied items for as long as they circulate "for classroom use."

If the faculty members inform the library that they intend to reuse the materials, the reserve librarian should arrange to purchase the reprints and keep accurate records of these requests and purchases. These records are crucial because the 
sion that it is necessary to seek permission from the copyright holder before placing photocopies of published materials on reserve.

While this policy has generated extra processing work for the reserve room staff in terms of corresponding with each copyright holder of an item to be copied for reserve, it has revealed the fact that very few publishers are interested in collecting royalties for nonprofit, educational copying of this nature. Since the program started (from late October 1977 through February 1978), 985 requests for permission to photocopy for reserve reading have been sent out. Of the total, a mere 23 , or slightly more than 2 percent of the requests, subsequently resulted in the library's making a royalty payment. The average cost per article was approximately $\$ 1.50$.

As indicated earlier, most of the publishers and copyright holders contacted have given the library permission, without charge, to copy their articles. The only requirement is that the library include on the first page of the copy full bibliographic credits. Some even specify the exact way in which this is to be done.

Originally, the responsibility for contacting publishers was entrusted to the library's Collections Development Department. The department created a form letter which was filled in with the appropriate information and mailed, together with a photocopy of the first page of the article to be copied, to the publisher whose permission to copy was sought. When it began to be clear that few transactions involved library funds, the program was transferred to the staff of the reserve reading room. The decision to pay royalty is left up to this staff. Royalty requests considered excessive prompted staff to discuss the issue with faculty to see if they still want an item copied. One publisher wanted $\$ 110$ for granting permission to copy eleven pages of a book. Needless to say, the library decided to purchase another copy of the title for reserve!

Although it has not yet occurred, faculty seeking to place their own photocopies on reserve will not be allowed to do so until the library has obtained permission from the copyright holder. In this way, the library will be able to protect itself from inadvertently placing on reserve photocopies which possibly were obtained in violation of the Copyright Law.

As long as faculty continue to place materials on reserve, multiple photocopies of short works, especially of periodical articles, appear to be the most efficient and least expensive solution for the library. And until there is a definitive interpretation of the law in regard to copying for reserve, Northern's library will continue its policy of requesting permission from the copyright holders.-Lester $\boldsymbol{K}$. Smith, Acting Director, Northern Illinois University Libraries. library is far more liable than an individual faculty member to be cited with violations of the law.

As Martell says, although in a different context, "it certainly would not be prudent to sit back and rely on the good faith of the faculty to abide by the new law." In fact, his article would have addressed the problem more directly had he kept this acerb hut realistic observation in mind.

In addition, the library should (logically) share the cost of the reprints with the respective academic departments since purchasing reprints and maintaining the attendant records will add appreciably to the cost of offering the reserve service.

The reserve system of the past, while an obvious convenience for teachers, epitomized just the sort of unfair royalty deprivation the new copyright law attempts to correct: Photocopies, after all, circumvent book, pamphlet, and journal buying. Although I have some reservations about the CONTU Guidelines, I certainly endorse the spirit of the new copyright law. Moreover, in contrast to Charles Martell, I advocate focusing the practical responsibility for this honorable undertaking directly in the library while spreading the financial responsibilities across a campus-wide base.-Cordelia W. Swinton, chief, Lending Services, Pennsylvania State University.

\section{Richard Dougherty Enters ALA Presidential Race}

Richard Dougherty has entered this year's ALA presidential race. $\mathrm{He}$ is university librarian, University of California, Berkeley, and edits the Joumal of Academic Librarianship. A councilor since 1969, he served on the executive board in 1972-76. Dougherty was nominated by petition.

\section{ACRL College Section Program}

The College Section will discuss future directions for the section at its annual membership meeting in Chicago. Those attending will participate in small discussion/planning group sessions that will focus on membership interests and concerns for future section activities. Members are urged to attend and to send ideas and suggestions for consideration by the section to Mary Louise B. Cobb, Chair, 26 Quarry Rd., Apt. 38, Waterville, ME 04901 .

The College Section will also cosponsor the ACRL annual conference program in Chicago. 